International Journal of Social Science and Economic Research

ISSN: 2455-8834

Volume: 05, Issue: 06 "June 2020"

\title{
MONETARY POLICY AND AGRICULTURAL PRODUCTIVITY IN NIGERIA
}

\author{
${ }^{1}$ Donny Sigah, Ayibazuomuno; ${ }^{2}$ Ibeinmo Friday, Cookey \\ ${ }^{1,2}$ University of Africa, Toru-Orua, Bayelsa State, Nigeria.
}

DOI: 10.46609/IJSSER.2020.v05i06.013 URL: https://doi.org/10.46609/IJSSER.2020.v05i06.013

\begin{abstract}
This study examines the impact of monetary policy on the agricultural sector performance in Nigeria from 1981 to 2018. In specific terms, the study investigated the impact of Money Supply (MS2), Interest Rate (INR), Credit to the Agricultural Sector (CREDAGR), and Broad Money Growth Rate (BROADMGR) on the Performance of Agricultural sector. The data used in this study were sourced from CBN statistical bulletin. The Autoregressive Distributed Lag (ARDL) econometric technique was used to estimate the agricultural performance model. The choice of this econometric technique is premised on the Augmented Dickey-Fuller (ADF) and the PhillipPerron (PP) test which shows that not all the time series are integrated of order one and the existence of a long run relationship as shown by the bound test. The ARDL result revealed the existence of long run relationship among the variables. From the findings, there is evidence of variation in the effect of the examined monetary policy instruments on the performance of the agricultural sector. This study concludes that the effect of increase in money supply is not instantaneous but rather requires at least three years before yielding positive and significant impact on the performance of the agricultural sector. Interest rate proved to be an inconsequential monetary policy instrument for influencing performance in the agricultural sector. Growth rate in broad money started impacting positively on performance of the agricultural sector the following year after an increase in a fiscal year. The study therefore recommends an expansionary monetary policy option with regards to growth rate in broad money (i.e. M2) and bank credit to the agricultural sector. Less attention should be paid to interest rate in effort to boost growth in the agricultural sector in Nigeria.
\end{abstract}

Keywords: Monetary policy, Money supply, Interest rate, Broad money growth rate, Credit to agricultural sector. 


\section{International Journal of Social Science and Economic Research}

ISSN: $2455-8834$

Volume: 05, Issue: 06 "June 2020"

\section{INTRODUCTION}

Monetary policy is one of the macroeconomic instruments with which monetary authority in a country employed in the management of its economy to attain predetermine objectives (Imoughele \& Ismaila, 2015). It entails those actions initiated by the Central Bank which aim at controlling the cost and availability of credits (Nwankwo, 1991).

For most economies, the fundamental objectives of monetary policy include price stability, maintenance of balance of payments equilibrium, and promotion of employment, output growth and sustainable development. These objectives are necessary for the attainment of internal and external balance of value of money and promotion of long run economic growth (Imoughele \& Ismaila, 2015). Gbosi (2002) posits that monetary policy aims at controlling money supply so as to counteract all undesirable trends in the economy, these undesirable trends may include; unemployment, inflation, sluggish economic growth or disequilibrium in the Balance of Payments.

Ajisafe \& Folorunso (2002) noted that the objectives of monetary policy includes increase in Gross Domestic Product growth rate, reduction in the rates of inflation and unemployment, improvement in the balance of payments, accumulation of financial savings and external reserves as well as stability in Naira exchange. The Keynesian theory postulated that changes in the money supply affect aggregate expenditure, output and balance of payment through the changes in the interest rate and thus this mechanism works indirectly. Monetarism concludes that monetary expansions influence the real variables such as output and employment in the shortrun, while the nominal variables such as nominal national income, interest rates and prices are influenced in the long-run.

Fasanya, Onakoya \& Agboluaje (2013) asserted that since the establishment of the Central Bank of Nigeria (CBN) in 1959, the bank has continued to play the traditional role expected of a central bank, which is the regulation of the stock of money in such a way as to promote the social welfare. Nwosa (2011) established that there have been various regimes of monetary policy in Nigeria some times, monetary policy is tight and at other times it is loose mostly used to stabilize prices and enhance the real sector performance.

One of the goals of any nation is to grow the agricultural sector. Efforts to grow the agricultural sector in Nigeria through the instrumentality of monetary policy include, but not limited to, Agricultural Credit Guarantee Scheme Fund (ACGSF) and the Nigerian Agricultural and Cooperative Bank (NACB). But yet there still exist conflicting evidence on the impact of these monetary policy measures on the agricultural sector. From the foregoing, this study attempts to 
examine the impact of monetary policy on productivity of the agricultural sector. The following objectives were achieved in the paper:

i. provision of empirical evidence on the impact of money supply on agricultural productivity in Nigeria between 1981 and 2018;

ii. provision of empirical evidence on the impact of interest rate on agricultural productivity in Nigeria between 1981 and 2018;

iii. provision of empirical evidence on the impact of credit to the agricultural sector on agricultural productivity in Nigeria between 1981 and 2018; and

iv. provision of empirical evidence on the impact of broad money (M2) growth rate on agricultural productivity in Nigeria between 1981 and 2018.

The following null hypotheses were also tested:

i. $\quad \mathrm{H}_{0}$ : Money supply has a significant impact on agricultural productivity.

ii. $\quad \mathrm{H}_{0}$ : Interest rate has a significant impact on agricultural productivity.

iii. $\mathrm{H}_{0}$ : Credit to the agricultural sector has a significant impact on agricultural productivity.

iv. $\quad \mathrm{H}_{0}$ : Broad money growth rate has a significant impact on agricultural productivity.

\section{LITERATURE REVIEW}

\subsection{Review of Theoretical Literature}

\section{The Classical Monetary Theory}

The classical theory, credited to Adam Smith, David Ricardo, and others attempts to explain the determination, savings and investment with respect to money. The classical model was built on Say's law of markets which states that "supply creates its own demand". Thus, classical economists believe that the economy automatically tends towards full employment level (Udude, 2014). Theory shows how money affects the economy. It may be considered in terms of the equation of Exchange:

$$
\mathrm{MV}=\mathrm{PY} \text {. }
$$

In the transaction version - associated with Fisher and Newcomb, some assumptions were made: that the quantity of money $(\mathrm{m})$ is determined independently of other variable, velocity of circulation (V) is taken as constant, the volume of transactions (T) is also considered constant. Thus, of price (p) and the assumption of full employment of the economy, the equation of exchange is given as: 


\section{International Journal of Social Science and Economic Research}

ISSN: $2455-8834$

Volume: 05, Issue: 06 "June 2020"

$$
\mathrm{MV}=\mathrm{PT}
$$

which can readily establish the production that - the level of price is a function of the supply of money. That is, $\mathrm{p}=\mathrm{F}(\mathrm{m})$ which implies that, any change in price changes money supply. In cash balances version - associated with Walras, Marshall, Wicksell and Pigou, the neoclassical school (Cambridge school), changed the focus of the quantity theory of without changing its underlying assumptions (Udude, 2014). This version focuses on the fraction (K) of income, held as money balances. The Cambridge version can be expressed as:

$$
\mathrm{M}=\mathrm{Kpy}
$$

where $\mathrm{K}=$ Fraction of income, $\mathrm{M}=\mathrm{Quantity}$ of money, $\mathrm{P}=$ price level, $\mathrm{y}=$ value of goods and services. The $\mathrm{K}$ in the Cambridge equation is merely inversion of $\mathrm{V}$, the income Velocity of money balances, in the original formulation of quantity theory. This version directs attention to the determinants of demand for money, rather than the effects of changes in the supply money (Anyanwu, 1993).

\section{Keynesian Theory}

The Keynesian model assumes a close economy and a perfect competitive market with fairly price- interest aggregate supply function. The economy is also assumed not to exist at employment equilibrium and also that it works only in the short run because as Keynes aptly puts it "In the long run, we also will be dead". In other records, they were not interested in the quantity theory per se (Udude, 2014). For the Keynesian, monetary policy works by influencing interest rate which influences investment decisions and consequently, output and income via the multiplies process. Thus, the Keynesian theory is a rejection of Say's Law and the notion that the economy is self-regulating.

\section{The Monetarist Theory}

The monetarist essentially adopted Fisher's equation of exchange to illustrate their theory, as a theory of demand for money and not a theory of output price and money income by making a functional relationship between the quantities of real balances demanded a limited number of variables. Monetarists like Friedman emphasized money supply as the key factor affecting the wellbeing of the economy. Thus, in order to promote steady of growth rate, the money supply should grow at a fixed rate, instead of being regulated and altered by the monetary authorities (Udude, 2014). Friedman equally argued that since money supply is substitutive not just for bonds but also for many goods and services, changes in money supply will therefore have both direct and indirect effects on spending and investment respectively such that demand for money 
International Journal of Social Science and Economic Research

ISSN: 2455-8834

Volume: 05, Issue: 06 "June 2020"

will depend upon the relative rates of return available or different competing assets in which wealth can be (Udude, 2014).

\subsection{Conceptual Review}

Monetary Policy: Monetary policy is concerned with discretionary control of money supply by the monetary authorities (Central Bank with Central Government) in other to achieve stated or desired economic goals. Governments try to control the money supply because most governments believe that its rate of growth has an effect on the rate of inflation (Abata, Kehinde \& Bolarinwa, 2012). Hence monetary policy comprises those government actions designed to influence the behaviour of the monetary sector. Monetary Policy is the deliberate use of monetary instruments (direct and indirect) at the disposal of monetary authorities such as central bank in order to achieve macroeconomic stability (Dwivedi, 2005). This is where a deliberate change in monetary variable influences the movement of many other variables in the monetary sector (Abata, Kehinde \& Bolarinwa, 2012). Three basic kinds of monetary policy decisions can be made about:

a) The amount of money in circulation;

b) The level of interest rate

c) The functions of credit markets and the banking system (Ogunjimi, 1997).

The combination of these measures is designed to regulate the value, supply and cost of money in an economy, in line with the level of economic activity.

\section{Empirical Literature}

Ashafa and Jooste (2007) evaluated agricultural price response to monetary policy in South Africa using monthly data and Johansen cointegration as well as Vector Error Correction Model (VECM). The study established a long run relationship between agricultural prices and monetary policy.

Using quarterly data from 1986 - 2008, Nwosa and Saibu (2012) investigated the transmission channels of monetary policy impulses on sectoral output growth in Nigeria. The study found interest rate channel as most effective channel in transmitting monetary policy to agriculture and manufacturing sectors.

Christopher and Akorah (2012) examined the impact of monetary policy on agricultural development in Nigeria. The study adopted the OLS method. Findings show that CBN monetary instruments have played a crucial and significant role in improving the performance of 


\section{International Journal of Social Science and Economic Research}

ISSN: $2455-8834$

Volume: 05, Issue: 06 "June 2020"

agricultural sector. They further recommend that $\mathrm{CBN}$ should design more instruments that are more flexible.

Brian, Innocent, Kin and Abbyssinia (2014) examined monetary policy actions and agricultural sector outcomes: empirical evidence from South Africa. They adopted Vector Error Correction Mechanism (VECM). The study reveals that inflationary shocks and money market rates have inverse relationship with the performance of agricultural sector. They recommended that policy makers, monetary authorities and participants in the monetary arena should pay careful attention on the interaction of the agricultural sector and stock prices.

Ajudua, Davis and Osmond (2015) examined a review of monetary policy and the Nigerian agricultural sector performance. The study adopted the Ordinary Least Square (OLS) method. The study revealed that monetary policy instruments have direct relationship with the performance of agricultural sector.

Oboh, Tule and Ebuh (2019) examined the impact of monetary policy on agricultural performance in Nigeira for the period 1986 - 2016 using Autoregressive Distributed Lag (ARDL) approach, the study found a long run relationship between agriculture value-added and selected monetary policy variables. The study recommends among others the pursuit of expansionary (but not inflationary) monetary policy in order to improve value addition to the agricultural sector.

\section{RESEARCH METHOD}

Research Design: The quantitative research design was adopted for this study. This is so because the data used are numerical in nature. Specifically, the quantitative design approach of quasiexperimental design was used in this research. Secondary data were sourced from the CBN Statistical Bulletin.

Econometric Technique: The Autoregressive Distributive Lag (ARDL) was used to estimate the model after some formalpre-test (i.e. unit root and bound cointegration test) were conducted. The Augmented Dickey-Fuller test (ADF) and Phillip-Perron (PP) were the preferred unit root test as the ARDL bound cointegration test was also chosen since the time series are not integrated of the order i.e. a mix of $\mathrm{I}(1)$ and $\mathrm{I}(0)$.

Model Specification: The model was estimated based on the theory reviewed in this paper and the modification of model of Oboh, Tule and Ebuh (2019). The contribution of the agricultural sector to the growth of the economy was preferred as the measure of the performance of the agricultural sector. The predicting monetary policy variables are money supply (MSS), interest 
rate (INR), credit to the agricultural sector (CREDAGR), and broad money growth rate (BROADMGR). The ARDL model is specified thus:

$\mathrm{AGRIC}=f(\mathrm{MSS}, \mathrm{INR}, \mathrm{CREDAGR}, \mathrm{BROADMGR})(1)$

$$
\begin{aligned}
& \Delta\left[\log \left(A G R I C_{t}\right)\right]=\alpha+\beta T+\gamma_{1} \log \left(A G R I C_{t-1}\right)+\gamma_{2} \log \left(M S S_{t-1}\right)+\gamma_{3} \log \left(\operatorname{INTR}_{t-1}\right)+\gamma_{4} \log \left(\operatorname{CREDAGR}_{t-1}\right) \\
& +\gamma_{5} \log \left(\text { BROADMGR }_{t-1}\right)+\sum_{i=1}^{J} \lambda_{i} \Delta \log \left(A G R I C_{t-i}\right)+\sum_{j=0}^{K} \varphi_{j} \Delta \log \left(M S S_{t-j}\right)+\sum_{l=0}^{M} \phi_{l} \Delta \log \left(\operatorname{INTR}_{t-l}\right) \\
& +\sum_{k=0}^{N} \theta_{k} \Delta \log \left(\operatorname{CREDAGR}_{t-k}\right)+\sum_{n=0}^{Q} \psi_{n} \Delta \log \left(\text { BROADMGR }_{t-n}\right)+\varepsilon_{t}
\end{aligned}
$$

\section{RESULTS AND DISCUSSION}

\subsection{Unit Root Tests}

The Augmented Dickey Fuller (ADF) and Phillip Perron (PP) unit root tests result in table 4.1 shows that there is mix of order of integration i.e. I(0) and I(1). BRAODMGR is I(0) and other time series (i.e. AGRIC, INR, MSS and CREDAGR) are integrated of order one [i.e. I(1)]. The decision to adopt both $\mathrm{ADF}$ and PP as well as testing for inclusion of only constant $\left({ }^{\mathrm{C}}\right)$ term and constant \& trend $\left({ }^{\mathrm{CT}}\right.$ ) was informed by the low power of most unit root tests and the sensitivity of the test results to inclusion or exclusion of constant term and the constant $\&$ trend term.

Table 4.1: Unit Root Test Results for Time Series in Agricultural Sector Performance Model

\begin{tabular}{l|rrrr|rrrr}
\hline \multirow{2}{*}{ VARIABLE } & \multicolumn{5}{|c|}{ LEVEL } & \multicolumn{4}{c}{ 1ST DIFFERENCE $^{\mathbf{C}}$} \\
\cline { 2 - 9 } & ADF $^{\mathbf{C}}$ & ADF $^{\mathbf{C T}}$ & $\mathbf{P P}^{\mathbf{C}}$ & PP $^{\mathbf{C T}}$ & ADF $^{\mathbf{C}}$ & ADF $^{\mathbf{C T}}$ & PP $^{\mathbf{C}}$ & PP $^{\mathbf{C T}}$ \\
\hline LOG(AGRIC) & 0.02 & -2.06 & 0.02 & -2.10 & $-5.85^{*}$ & $-5.77^{*}$ & $-5.84^{*}$ & $-5.77^{*}$ \\
LOG(CREDAGR) & -1.28 & -2.28 & -2.38 & -2.18 & $-6.92^{*}$ & $-6.99^{*}$ & $-7.25^{*}$ & $-8.17^{*}$ \\
LOG(MSS) & -1.02 & -1.15 & -0.78 & -1.15 & $-3.83^{*}$ & $-3.98^{*}$ & $-3.77^{*}$ & $-3.84^{*}$ \\
INR & -2.44 & -5.06 & -3.48 & -3.31 & -2.84 & $-6.19 *$ & $-9.65^{*}$ & $-9.97 *$ \\
BROADMGR & $-3.81^{*}$ & $-.3 .82^{*}$ & $-3.75^{*}$ & $-3.82^{*}$ & & & & \\
\hline \hline
\end{tabular}

* represent $5 \%$ significance level

$A D F^{C}$ represent $A D F$ test with intercept, $A D F^{C T}$ represent $A D F$ test with Intercept \& Trend, $P P^{C}$ represent Phillip Perron test with Intercept\& $P P^{C T}$ Phillip Perron test with Intercept \& Trend.

Source: Author's Computation 
International Journal of Social Science and Economic Research

ISSN: 2455-8834

Volume: 05, Issue: 06 "June 2020"

\subsection{Cointegration Test for the Agricultural Sector Performance Model}

The bond cointegration test (proposed by Pesaran, Shin and Smith (2001) for a mix of order of integration) result presented in table 4.2 confirms the existence of a long run relationship (F-stat. of $5.47>$ upper bound I(1) statistics at 5\% critical value bounds of 4.57) between the time series.

Table 4.2: Bounds Cointegration Test Result

\begin{tabular}{|c|c|c|}
\hline Computed F-statistic & 5\% Upper Critical Bound [I(1)] & Decision \\
\hline 5.47 & 4.57 & Existence of a long-run relationship \\
\hline
\end{tabular}

Source: Author's Computation using Eviews 9

\subsection{ARDL Short run/Long Run Estimated Model}

Short run (panel A) and long run (panel B) results are reported in table 4.3 below:

Table 4.3: Estimated ARDL Model Result

Panel A: Short run Coefficients

\begin{tabular}{l|cccc}
\hline Variable & Coefficient & Std. Error & t-Statistic & Prob. \\
\hline & & & & \\
DLOG(CREDAGR) & -0.07 & 0.06 & -1.22 & 0.24 \\
DLOG(CREDAGR(-1)) & 0.05 & 0.07 & 0.79 & 0.44 \\
DLOG(CREDAGR(-2)) & 0.20 & 0.07 & 3.02 & 0.01 \\
DLOG(CREDAGR(-3)) & 0.07 & 0.07 & 1.15 & 0.27 \\
DLOG(MSS) & 5.46 & 1.88 & 2.91 & 0.01 \\
DLOG(MSS(-1)) & 3.58 & 2.27 & 1.57 & 0.13 \\
DLOG(MSS(-2)) & -0.52 & 2.60 & -0.20 & 0.84 \\
DLOG(MSS(-3)) & 6.61 & 2.14 & 3.10 & 0.01 \\
D(INR) & 0.00 & 0.00 & 0.37 & 0.72 \\
D(BROADMGR) & -0.04 & 0.02 & -2.93 & 0.01 \\
D(BROADMGR(-1)) & 0.05 & 0.02 & 2.44 & 0.03 \\
D(BROADMGR(-2)) & 0.05 & 0.02 & 3.03 & 0.01 \\
D(@TREND()) & 0.16 & 0.04 & 3.89 & 0.00 \\
CointEq(-1) & -0.69 & 0.17 & -4.08 & 0.00 \\
\hline \hline
\end{tabular}

Panel B: Long run Coefficients

\begin{tabular}{l|llll}
\hline Variable & Coefficient & Std. Error & t-Statistic & Prob. \\
\hline
\end{tabular}




\begin{tabular}{l|cccc} 
& & & & \\
LOG(CREDAGR) & -0.70 & 0.11 & -6.48 & 0.00 \\
LOG(MSS) & -0.13 & 0.16 & -0.81 & 0.43 \\
INR & 0.00 & 0.01 & 0.37 & 0.71 \\
BROADMGR & -0.31 & 0.09 & -3.34 & 0.00 \\
C & 6.53 & 0.26 & 24.93 & 0.00 \\
@TREND & 0.23 & 0.05 & 4.26 & 0.00 \\
\hline \hline
\end{tabular}

Source: Author's Computation using Eviews 9

\section{Short Run Dynamics (Panel A)}

The short run form of the model is presented in panel A of Table 4.3.

i. The impact of money supply was observed at different time lags. Firstly, the contemporaneous effect of money supply had a positive and significant impact on agricultural sector performance. Secondly, one year past of money supply (i.e. lag 1 of money supply) had a positive but insignificant impact on agricultural sector performance. Thirdly, two years past of money supply (i.e. lag 2 of money supply) had a negative but insignificant impact on agricultural sector performance. Lastly, three years past of money supply (i.e. lag 3 of money supply) had a positive and significant impact on agricultural sector performance.

ii. Interest rate (i.e. lending rate) had a positive but insignificant impact on agricultural sector performance.

iii. The impact of broad money (M2) growth rate was also observed at different time lags. The levels broad money (M2) growth rate had a negative and significant impact on agricultural sector performance. Secondly, one year past of broad money supply growth rate (i.e. lag 1 of broad money (M2) growth rate) had a positive and significant impact on agricultural sector performance. Lastly, two years past of broad money supply growth rate (i.e. lag 2 of broad money (M2) growth rate) had a positive and significant impact on agricultural sector performance.

iv. The impact of bank credit to the agricultural sector was also observed at different time lags. Firstly, levels bank credit to the agricultural sector had a negative and insignificant impact on agricultural sector performance. Secondly, one year past of bank credit to the agricultural sector (i.e. lag 1 of bank credit to the agricultural sector) had a positive and insignificant impact on agricultural sector performance. Thirdly, two years past of bank credit to the agricultural sector (i.e. lag 2 of bank credit to the agricultural sector) had a positive but significant impact on agricultural sector performance. Lastly, three years past of bank credit to the agricultural sector 
(i.e. lag 3 of bank credit to the agricultural sector) had a positive and insignificant impact on agricultural sector performance.

v. Lastly, the coefficient of the error correction term (i.e. -0.69) has the expected negative sign. The magnitude of the coefficient implies that the short run disequilibrium in the system can be reconciled at the speed of 69 percent.

\section{Long Run (Panel B)}

The long run form of the model is presented in panel B of Table 4.3. The result indicates that firstly, money supply appeared with a negative sign and insignificant impact on the performance of the agricultural sector in the long run. Secondly, interest rate (i.e. lending rate) appeared with a positive sign but not expected to significantly impact on the performance of the agricultural sector in the long run. Thirdly, broad money growth rate did not appear with the hypothesized positive sign and expected to significantly impact on the performance of the agricultural sector in the long run. Lastly, Credit to the agricultural sector did not appear with the hypothesized positive sign but expected to significantly impact on the performance of the agricultural sector in the long run.

\subsection{Post Estimation Tests}

Table 4.4: Post Estimation Tests for the Estimated Agricultural Sector Performance Model

\begin{tabular}{|c|c|c|c|c|}
\hline \multirow{2}{*}{$\mathbf{i}$} & \multirow{2}{*}{ Normality Test } & Jarque-Bera Statistics & Probability & Decision \\
\hline & & 4.17 & 0.12 & Data is Normally Distributed \\
\hline \multirow{2}{*}{ ii } & \multirow{2}{*}{$\begin{array}{c}\text { The Breusch-Godfrey } \\
\text { LM Result }\end{array}$} & F-Statistics & Probability & Decision \\
\hline & & 1.55 & 0.24 & Model Free from Autocorrelation \\
\hline \multirow{2}{*}{ iii } & \multirow{2}{*}{$\begin{array}{l}\text { The Breusch-Pagan- } \\
\text { Godfrey LM Result }\end{array}$} & F-Statistics & Probability & Decision \\
\hline & & 0.58 & 0.85 & Model Free from heteroskedasticity \\
\hline \multirow{2}{*}{ iv } & \multirow{2}{*}{ Ramsey RESET Test } & F-Statistics & Probability & Decision \\
\hline & & 0.37 & 0.54 & Model is correctly specified \\
\hline
\end{tabular}

Source: Author's Computation using Eviews 9

\section{i. Normality Test}

Since the p-value is $0.12>0.05$, the decision is to fail to reject the null hypothesis. We therefore conclude that the data is normally distributed. The model passed the normality test.

\section{ii. Serial Correlation Test}


International Journal of Social Science and Economic Research

ISSN: $2455-8834$

Volume: 05, Issue: 06 "June 2020"

The serial correlation test was done using Breusch-Godfrey LM test. Since the p-value is 0.24 $>0.05$, we reject the null hypothesis of the presence of autocorrelation. We therefore conclude that the specified model did not suffer from autocorrelation problem.

\section{iii. Heteroscedasticity Test}

From the Breusch-Pagan-Godfrey LM test coefficient and its associated p-value of $0.85>0.05$ suggest the rejection of the null hypothesis. We therefore conclude that the specified model did not suffer from heteroscedasticity problem. The model satisfied the homoscedasticity assumption.

\section{iv. Linearity Test}

Given the coefficient of the Ramsey RESET test and its associated p-value of $0.54>0.05$, we reject the null hypothesis of wrong specification and conclude that the model was well specified.

This shows that the estimated ARDL model passed all the tests and fit for policy recommendation.

\section{CONCLUSION AND RECOMMENDATIONS}

From the foregoing, we can state that there is evidence of variation in the effect of the examined monetary policy instruments on the performance of the agricultural sector. This study concludes that the effect of increase in money supply is not instantaneous but rather requires at least three years before yielding positive and significant impact on the performance of the agricultural sector. Interest rate proved to be an inconsequential monetary policy instrument for influencing performance in the agricultural sector. Growth rate in broad money started impacting positively on performance of the agricultural sector the following year after an increase in a fiscal year. This condition was also evident after increase in later (i.e. two and three previous) years. For bank credit to the agricultural sector to significantly influence output from the agricultural sector, at least a duration of one year after granting of such credit is required. Lastly, only broad money growth rate and bankcredit to the agricultural sector constitutes significant predictors of performance of the agricultural sector in the long run. The study therefore recommends an expansionary monetary policy option with regards to growth rate in broad money (i.e. M2) and bank credit to the agricultural sector. Less attention should be paid to interest rate in effort to boost growth in the agricultural sector in Nigeria. 


\section{International Journal of Social Science and Economic Research}

ISSN: $2455-8834$

Volume: 05, Issue: 06 "June 2020"

\section{REFERENCES}

Abata, M., Kehinde, J. S \& Bolarinwa, S. A. (2012).Fiscal/Monetary policy and economic growth in Nigeria: A theoretical exploration. International Journal of Academic Research in Economics and Management Sciences, 1(5), 75-78.

Ajisafe, R. A. and B. A. Folrunso, (2002).The relative effectiveness of fiscal and monetary policy in macroeconomic management in Nigeria. Afr. Econ. Bus. Rev., 3(1), 23-40.

Ajudua, E. I., Davis, O. J. P., \& Osmond, N. O. (2015). A review of monetary policy and the Nigerian agricultural sector performance. International Journal of Academic Research in Progressive Education and Development, 4(3), 70-86.

Ashafa, T. A \& Jooste, A. (2007). The effect of monetary changes on relative agricultural prices. Agrekon 46(4), 460 - 474 (Online) https://doi.org/10.1080/03031853

Brian, M., Innocent S., Kin, S., \& Abbyssinia, M. (2014). Monetary Policy actions and agricultural sector outcomes: empirical evidence from South Africa. Mediterranean Journal of Social Science, 5(1), 613-620.

Central Bank Nigeria (2002). Budget of economic growth and development. Bullion, 26(2) April/June.

Christopher, E., \& Akorah, C.C. (2002). The impact of monetary Policy on agricultural development in Nigeria (1970 - 2010). ISOR Journal of Humanities and Social Science, $5(5), 13-25$.

Gbosi, A. N. (2002). Contemporary Issues in Nigeria's Public Finance and Fiscal Policy. Abakaliki: Pack Publishers.

Gujarati, D. N., \& Sangeetha, T. (2007).Basic Econometrics. New Delhi: Tata McGraw Hill.

Ismaila, M., \& Imughele L. E (2015). Macroeconomic determinants of growth in Nigeria: A Cointegration Approach. International Journal of Academic Research in Economics and Management, 4(1), 34-46.

Nwanyanwu, O. J. (2008). An analysis of banks' credit on the Nigerian economic growth (19922008). Jos Journal of Economics,4(1), 43-58.

Nwosa, L. P. \& Saibu, M. O. (2011). Effects of monetary policy on sectoral output growth in Nigeria (1986 - 2008). Journal of Economics and Behavioural Studies, 2(6). Pp. 245 254. 


\section{International Journal of Social Science and Economic Research}

ISSN: $2455-8834$

Volume: 05, Issue: 06 "June 2020"

Oboh, V. U., Tule, M. K \& Ebuh, G. U. (2019). Does monetary policy matter for agricultural sector performance? Empirical evidence from Nigeria. Journal of Economics and Sustainable Development. Vol. 10 (12). DOI: 10.7176/JESD

Ohale, L. \& Onyema, J. I. (2002). Foundations of Macroeconomics. Owerri: Springfield publishers Limited.

Tom-Ekine, N. (2013). Macroeconomics: The Frontier of Public Policy ( $3^{\text {rd }}$ Ed.). Port Harcourt.

Time Series Used in the Analysis, 1981 - 2018.

\begin{tabular}{|c|c|c|c|c|c|}
\hline Year & $\begin{array}{c}\text { Money Supply } \\
\text { (N Billion) }\end{array}$ & $\begin{array}{c}\text { Interest Rate } \\
(\%)\end{array}$ & $\begin{array}{c}\text { Credit to the } \\
\text { Agricultural Sector } \\
\text { (N Billion) }\end{array}$ & $\begin{array}{c}\text { Agricultural Sector } \\
\text { Output (N Billion) }\end{array}$ & $\begin{array}{c}\text { Broad } \\
\text { Money } \\
\text { Growth Rate } \\
\text { (\%) }\end{array}$ \\
\hline 1981 & 16.16 & 7.75 & 0.6 & 2364.37 & 7.02 \\
\hline 1982 & 18.09 & 10.25 & 0.8 & 2425.96 & 11.95 \\
\hline 1983 & 20.88 & 10 & 0.9 & 2409.08 & 15.39 \\
\hline 1984 & 23.37 & 12.5 & 1.1 & 2303.51 & 11.93 \\
\hline 1985 & 26.28 & 9.25 & 1.3 & 2731.06 & 12.44 \\
\hline 1986 & 27.39 & 10.5 & 1.8 & 2986.84 & 4.23 \\
\hline 1987 & 33.67 & 17.5 & 2.4 & 2891.67 & 22.92 \\
\hline 1988 & 45.45 & 16.5 & 3.1 & 3174.57 & 34.99 \\
\hline 1989 & 47.06 & 26.8 & 3.5 & 3325.95 & 3.54 \\
\hline 1990 & 68.66 & 25.5 & 4.2 & 3464.72 & 45.92 \\
\hline 1991 & 87.50 & 20.01 & 5 & 3590.84 & 27.43 \\
\hline 1992 & 129.09 & 29.8 & 7 & 3674.79 & 47.53 \\
\hline 1993 & 198.48 & 18.32 & 10.8 & 3743.67 & 53.76 \\
\hline 1994 & 266.94 & 21 & 17.8 & 3839.68 & 34.50 \\
\hline 1995 & 318.76 & 20.18 & 25.3 & 3977.38 & 19.41 \\
\hline
\end{tabular}


International Journal of Social Science and Economic Research

ISSN: 2455-8834

Volume: 05, Issue: 06 "June 2020"

\begin{tabular}{|c|c|c|c|c|c|}
\hline 1996 & 370.33 & 19.74 & 33.3 & 4133.55 & 16.18 \\
\hline 1997 & 429.73 & 13.54 & 27.9 & 4305.68 & 16.04 \\
\hline 1998 & 525.64 & 18.29 & 27.2 & 4475.24 & 22.32 \\
\hline 1999 & 699.73 & 21.32 & 31 & 4703.64 & 33.12 \\
\hline 2000 & 1036.08 & 17.98 & 41 & 4840.97 & 48.07 \\
\hline 2001 & 1315.87 & 18.29 & 55.8 & 5024.54 & 27.00 \\
\hline 2002 & 1599.49 & 24.85 & 59.8 & 7817.08 & 21.55 \\
\hline 2003 & 1985.19 & 20.71 & 62.1 & 8364.83 & 24.11 \\
\hline 2004 & 2263.59 & 19.18 & 67.7 & 8888.57 & 14.02 \\
\hline 2005 & 2814.85 & 17.95 & 48.6 & 9516.99 & 24.35 \\
\hline 2006 & 4027.90 & 17.26 & 49.4 & 10222.47 & 43.09 \\
\hline 2007 & 5809.83 & 16.94 & 149.6 & 10958.47 & 44.24 \\
\hline 2008 & 9166.84 & 15.14 & 106.4 & 11645.37 & 57.78 \\
\hline 2009 & 10780.63 & 18.99 & 135.7 & 12330.33 & 17.60 \\
\hline 2010 & 11525.53 & 17.59 & 128.4 & 13048.89 & 6.91 \\
\hline 2011 & 13303.49 & 16.02 & 255.2 & 13429.38 & 15.43 \\
\hline 2012 & 15480.85 & 16.79 & 316.4 & 14329.71 & 16.37 \\
\hline 2013 & 15681.26 & 16.72 & 343.7 & 14750.52 & 1.29 \\
\hline 2014 & 18885.50 & 16.55 & 478.9 & 15380.39 & 20.43 \\
\hline 2015 & 20029.83 & 16.85 & 449.3 & 15952.22 & 6.06 \\
\hline 2016 & 23591.73 & 16.87 & 525.9 & 16607.34 & 17.78 \\
\hline 2017 & 22594.87 & 17.58 & 503.1 & 17179.50 & -4.23 \\
\hline 2018 & 25466.92 & 16.91 & 556.7 & 17544.15 & 12.71 \\
\hline
\end{tabular}

Source: Central Bank of Nigeria (CBN) Statistical Bulletin Volume 29, 2018. 